\title{
LANGUAGE AND MEMORY IN BORGES' "FUNES, THE MEMORIOUS"
}

Elyce Rae Helford

IN "FUMES, THE Memorious," Borges embarks upon an examination of the nature of communication. Ireneo Funes, the object of this fictional testimonial, is thrown from a horse to find himself physically crippled, yet, as he sees it, mentally enlightened. He finds he has become capable of complete and perfect recall. He can reconstruct his most distant memory, intuit the number of stars in the sky, or recite entire books he has read, all with equal ease:

On falling from the horse, he lost consciousness; when he recovered it, the present was almost intolerable it was so rich and bright; the same was true of the most ancient and most trivial memories. A little later he realized that he was crippled. This fact scarcely interested him. He reasoned (or felt) that immobility was a minimum price to pay. And now, his perception and his memory were infallible. ${ }^{1}$

However, for this enlightenment, Funes has simultaneously forfeited the elements essential for the creation of original thought: omission and abstraction. The narrator reflects:

Without effort, he had learned English, French, Portuguese, Latin. I suspect, nevertheless, that he was not very capable of thought. To think is to forget a difference, to generalize, to abstract. In the overly replete world of Funes there were nothing but details, almost contiguous details. ${ }^{2}$

For Funes to communicate his experience to a listener, the use of language is necessary. Funes must access a common code between himself and the narrator of the story and manipulate it in the manner which expresses his thoughts most clearly. Manipulation of language, however, requires a distillation process which would be highly problematic in Funes' complex and alien world of recall. To explain this difficulty more concretely, it is beneficial to have a model from which to work.

Ferdinand de Saussure developed a system of language based on 
the relationships between words. He wrote, "Language is a system of interdependent terms in which the value of each term results solely from the presence of others." ${ }^{3}$ According to Saussure, these relationships can be most clearly understood as the functions of two perpendicular axes. He terms these axes the syntagmatic (or "horizontal") and the associative (or "vertical").

Syntagmatic relationships are those of sequential movement through time. Each word derives meaning from those which precede and follow it. Terence Hawkes terms this process the "pattern of positioning." "The associative axis is based on specific word selection at each syntagmatic "moment" of communication. When one wishes to say or write something, each word must be chosen through a process of elimination. Of Saussure's conception of the associative function, Hawkes writes:

. . . each word will also have relationships with other words in the language which do not occur at this point in time, but are capable of doing so. ... And these other words . . . help, by not being chosen, to define the meaning of the word which has. It obviously follows from our notion of language as a self-contained structure that the absence of certain words partly creates and certainly winnows and refines the meanings of those that are present. ... ${ }^{5}$

According to this model, then, a person continually selects one word in favor of another in order to express his or her thoughts in the clearest possible manner. In everyday speech these selections are made almost without thought, for as each word is selected for a given utterance, the "list" from which the next may be chosen becomes smaller, due to such constraints as context and grammar; therefore, once an idea has begun to be expressed, continuing and completing the thought happens almost automatically. This observation, I feel, is crucial to understanding Funes' world and the nature of language for Borges.

Because Funes' altered state of mind causes him to remember and weigh all thoughts, words, and events equally, it seems nearly inconceivable that he is able to make the decisions and selections required for communication. Even if he is granted the retention of every-day "mindless" speech, he must still order and place relative value on each general thought he wishes to express. If he opts to describe the moment he fell from his horse, for instance, he would be simultaneously and equally forcefully compelled to reveal the sensation of the fall, his immediate physical and emotional response to the fall, the reason for the fall, the horse's reaction to the fall, the reactions of anyone nearby to the fall, the appearance of the sky at the moment of the fall, ad infinitim. For each thought, if not each individual word, movement along the syntagmatic axis would necessarily cause great ambivalence due to the selective demands of the associative axis. 
Yet Funes does speak. Borges forces his readers to accept the paradox of this man's "enlightened" existence by making it theoretically improbable (if not impossible) for Funes to communicate his message while revealing, albeit through indirect discourse, that he does. Clearly, Funes must be allowed to speak, for the text demands that he relate his story. However, for Borges it is equally important that Funes speak precisely because he should not be able to. The paradox is intentional and thought-provoking.

In a parenthetical note, John Sturrock muses over this puzzle from another vantage point:

. . . it is not quite clear from the story how Funes could ever manage to tell his story, as he does, to the narrator during the night they spend together; the narrator is careful to tell us that the story we are reading is his no doubt defective account of what he heard from Funes, but the fact that Funes was able to say anything at all about himself indicates an unsuspected gift for abstraction. ${ }^{6}$

Sturrock is concerned less with Funes' ability to speak than with his ability to speak of "self," a concept which requires reflective and abstract thought. Yet, if one considers the manipulation of language to be inherently personal, then Sturrock's point can lead to a more general understanding. The work of Freud helps clarify this.

Jacques Derrida, in his reading of Freud, proposes a theory which unites subject/self with subject/topic of communication. Elizabeth Wright provides an excellent summary of this reading:

In Derrida's reading of Freud ... the unconscious, through memories nonverbal as well as verbal . . . becomes active in the production of meaning, its traces being present in every word . . . for Derrida the unconscious is a weave of pure traces . . . [it] is operative in language all the time (seeing text as psyche). ${ }^{7}$

According to this theory, then, communication itself is impossible without a personal bias, however unconscious this bias may often be. Although Funes can not articulate or even acknowledge a "self" (for this requires abstract thought) his communication is still affected by it.

The nature of communication is also examined through the mind of the narrator. The narrator is quick to remind his audience that his memory, unlike Funes', is fallable. He can only replicate his dialogue with Funes as accurately as he can remember it, selecting his words not for their literal accuracy, but for their ability to convey the sense of what he feels was said.

I shall not attempt to reproduce his words, now irrecoverable. I prefer truthfully to make a resumé of the many things Ireneo told me. The indirect style is remote and weak; I know that I sacrifice the effectiveness of my narrative; but let my readers imagine the nebulous sentences which clouded that night. ${ }^{8}$

It is noteworthy that Borges chooses the word resumé for the format of the narrator's description. A resumé can be a recitation of facts, yet the word can also mean an approximation or summary. This 
recalls the narrator's ability to abstract and generalize, while also emphasizing the inexactness of common recall.

Of the two men, Funes clearly experiences the greater disability. This is revealed by his failed attempt at redesigning the system of enumeration. Even when Funes succeeds in selecting his new, more concise numerical terms (such as Maximo Perez instead of seven thousand thirteen), he still can not understand the workings of the system. Sturrock writes:

It is a sequence when it ought to have been a series, and if the original values of

Funes' terms were lost they might be arranged in any order at all, they are meaningful only for as long as they can be translated back into the system they have replaced. ${ }^{9}$

Funes' new "numbers" form a sequence whose elements derive meaning only when mapped onto the present numerical system, which is a series. In a sequence, the only relative requirement between elements is spatial; whereas in a series, each term must have some explicit relationship to others which enables some form of internal calculation, predictions, and the generation of new elements. This is perhaps made most clear by the definition of a mathematical series in Webster's Unabridged Dictionary: "an infinite number of terms following one another, each of which is derived from one or more of the preceding ones, by a fixed law...." Funes' numbers follow no explicit laws, so they fail as a series.

If the reader has not made the discovery that Funes succeeded in producing a mere sequence, the narrator of the story states this directly:

I attempted to explain that this rhapsody of unconnected terms was precisely the contrary of a system of enumeration. I said that to say three hundred and sixty-five was to say three hundreds, six tens, five units: an analysis which does not exist in such numbers as The Negro Timoteo or The Flesh Blanket. Funes did not understand me, or did not wish to understand me. ${ }^{10}$

Funes clearly fails in his attempt because he is incapable of seeing the system as such in order to understand its overall construction and significance. Substituting elements without comprehension, or even acknowledgment of the principles used to create the system will rarely produce a useful new system (any exceptions would probably occur by chance).

From its very title, "Funes, the Memorious" is a story about the function of memory. Despite the fact that I have chosen to examine the story in terms of communication and language, memory plays an important role in such an analysis. Richard J. Christ discusses the theme of memory as dominant in the fiction of Borges:

Borges likes to write stories about events filtered through individual or collective memory because in his view the perspective of memory serves to diminish the 
extraneous and emphasize the essential. ${ }^{11}$

This brief comment helps to explain a great deal about Borges' careful and frequently fascinating attention to point of view in his fiction, as well as his attention to other closely related stylistic details. Yet in "Funes, the Memorious," "perspective of memory" is absent. In order to convey the workings of the memory as he understands it, Borges portrays an individual whose memory functions in a precisely inverse fashion; Funes' memory is not exclusive, but inclusive.

Explicitly, Borges refers to his piece only as "a long metaphor of insomnia," recalling the narrator's words:

It was difficult for him to sleep. To sleep is to be abstracted from the world: Funes, on his back in his cot, in the shadows, imagined every crevice and every moulding of the various houses which surrounded him. ${ }^{12}$

And Borges' words seem to me to suffice as a statement on the infinite memory of Funes, for it is rare, and arguably even a mistake for authors to speak extensively of their own works. The potential is too great that external interpretations will be suppressed.

Christ, on the other hand (or perhaps the same hand), refers to the story as illustrative of the "tragic absurdity of absolute memory."13 Absolutes are rare in life, and thus highly arresting and effective when used in literature. Aside from Christ's use of the term "absolute" in reference to Funes' memory, he also alludes to "collective memory," and Borges himself bestows the epithet "the Memorious" upon his protagonist. Such evidence helps to advance the popular critical assertion that Funes is an archetypal figure.

Sturrock writes, "The ultimate paradox of Funes . . . is that he is himself an abstraction: he is the archetype of Memory."14 According to this critic's conception, Funes must be seen as both man and myth. This causes another paradox, because a mythic figure is an abstraction, and this makes Funes exactly that which he is incapable of comprehending.

Carl Jung's theory of archetypes relies heavily on the concept of memory. He partially defines archetypes as "the inherited possibilities of human imagination as it was from time immemorial." ${ }^{15}$ Obviously, the word imagination is problematic in relation to Funes, but this definition seems to reflect Funes' method of recall well. In a sense, Funes might be termed an archetype of archetypes. Yet this assertion is limited by the fact that Funes' memory does not extend further than his own experiences. His memory may be collective within the frame of his own life, but it is not culturally collective.

Earlier in this discussion, I briefly examined the conception that all communication reflects some level of internal vision, that non-"selfreflected" speech is impossible given Freud's understanding of the 
unconscious mind. Jung, however, deconstructs this argument through the concept of the "collective unconscious." Wright again provides a helpful summary:

These primordial images, issuing from a "collective unconscious," collective "because it is detached from anything personal and is common to all" . . . manifest themselves in bizarre and extravagant fantasies which threaten to dissolve the boundaries between self and world. ${ }^{16}$

Freud considers the unconscious a signifier of self in all communication whereas Jung considers the memories of the collective unconscious an impersonal and ultimately more powerful force. In other words, Freud holds that the world is reflected through patterns in the self, while Jung holds that the self is reflected through patterns in the world. Such a conception of the self is perhaps more easily applied to Funes.

In this study, I have primarily concentrated on the inabilities and weaknesses of all-inclusive memory. Yet Funes considers himself blessed, and this must be taken into account. The narrator's intention in writing down his memories of Funes is to provide a testimonial. Furthermore, the narrator chooses to include a curious epithet written by another of Funes' acquaintances. Pedro Leandro Ipulche is said to have written that "Funes was a precursor of superman, 'an untamed and vernacular Zarathustra.' "17 Analysis of this epithet yields an additional, yet somewhat contradictory interpretation of the nature of Funes. "Untamed" well defines Funes' transformed state. He can not completely control his power; it eventually destroys him. "Vernacular" seems to be a general reference to the "certain incurable limitations" of his heritage and environment. And "Zarathustra" (or Zoroaster), the founder of the pagan religion Zoroastrianism, denotes an inspired and inspirational teacher of spiritual matters, calling Nietzsche to mind. For Ipulche, then, Funes represents an uncontrolled, inspiring force which operates through a common man.

This may well denote Funes; however, I would posit it as an excellent epithet for Borges himself. Through his fiction emerges a voice beyond the elements which make up this man. He seems to address this internal "force" in the short prose piece "Borges and I":

It's the other man, to Borges, that things happen. . . . It would be an exaggeration to say that we are on bad terms; I live, I let myself live, so that Borges can weave his tales and poems, and those tales and poems are my justification. It is not hard for me to admit that he has managed to write a few worthwhile pages. . . . Years ago, I tried ridding myself of him and went from myths of the outlying slums of the city to games with time and infinity, but those games are now part of Borges and I will have to turn to other things....

Which of us is writing this page I don't know. ${ }^{18}$

Ultimately, the reader of this essay may be left as steeped in paradox 
as $\mathrm{s} /$ he was when reading the story which it examines. A feeling of inconclusiveness occurs primarily because any interpretation of the story remains necessarily incomplete. Examination of the figure of Funes resists closure just as Funes' memory does. For every probable angle of interpretation, Borges has encouraged additional and often opposing angles: Funes should not be able to communicate, yet he does; he lives as a man, yet functions as an archetype; he is both tragic victim and superman; etc. It is only possible, then, to accept attempts to understand Funes as partial truths: valuable in themselves, yet never final.

\section{NOTES}

1 Jorge Luis Borges, Ficciones (New York: Grove Press, 1962), p. 112.

2 Borges, p. 115.

3 Ferdinand de Saussure as quoted in Terence Hawkes, Structuralism and Semiotics (Berkeley: University of California Press, 1977), p. 26.

4 Hawkes, p. 26.

5 Hawkes, p. 27.

6 John Sturrock, Paper Tigers: The Ideal Fictions of Jorge' Luis Borges (Oxford: Clarendon Press, 1977), p. 112.

7 Elizabeth Wright, Psychoanalytical Criticism: Theory in Practice, (New York: Methuen, 1984), p. 134.

8 Borges, p. 111.

9 Sturrock, pp. 111-12.

10 Borges, p. 113.

11 Ronald J. Christ, The Narrow Act: Borges' Art of Allusion (New York: New York University Press, 1969), p. 9.

12 Borges, p. 115.

13 Christ, p. 9.

14 Sturrock, p. 112.

15 Carl Jung as quoted in Wright, p. 70.

16 Wright, p. 70.

17 Borges, p. 108.

18 Jorge Luis Borges, Borges: A Reader, eds. Emir Rodriguez Monegal and Alastair Reid (New York: E. P. Dutton, 1981), p. 278-79. 